\title{
The effect of adolescent reproductive health education on premarital sexual behavior
}

\author{
Murdiningsih, Rohaya, St Hindun, Ocktariyana \\ Department of Midwifery, Politeknik Kesehatan Palembang, Ministry of Health, Indonesia
}

\begin{tabular}{|c|c|}
\hline Article Info & ABSTRACT \\
\hline $\begin{array}{l}\text { Article history: } \\
\text { Received Mar 31, } 2020 \\
\text { Revised Jul 28, 2020 } \\
\text { Accepted Sep 8, } 2020\end{array}$ & $\begin{array}{l}\text { A lack of communication, support, and information from parents on sexual } \\
\text { issues are involved an inability to prevent or intervene in the sexual activity } \\
\text { of adolescents. This study aimed to determine the effect of adolescent } \\
\text { reproductive health education on premarital sexual behavior in Palembang, } \\
\text { Indonesia. This study was an experimental design with pre and post- } \\
\text { intervention. The } 192 \text { students were obtained based on the criteria of samples }\end{array}$ \\
\hline $\begin{array}{l}\text { Keywords: } \\
\text { Adolescent } \\
\text { Premarital sexual behavior } \\
\text { Reproductive health education }\end{array}$ & $\begin{array}{l}\text { required. The result of bivariate analysis between the Chi-Square } \\
\text { confounding variable and premarital sexual behavior after the intervention } \\
\text { shows that there is a significant relationship between knowledge about sex, } \\
\text { reproductive health, and attitudes with premarital sexual behavior. There is a } \\
\text { significant relationship between control behavior and sexual behavior after } \\
\text { performing the intervention }(\mathrm{p}=0.00) \text {. The result of multivariate shows that } \\
\text { there is a dominant variable that is the variable of knowledge about } \\
\text { reproductive health }(\mathrm{p}=0.00) \text {. This study suggested that information about } \\
\text { adolescent reproductive health should be included in the curriculum, } \\
\text { especially in Biology class. }\end{array}$ \\
\hline
\end{tabular}

This is an open access article under the CC BY-SA license.

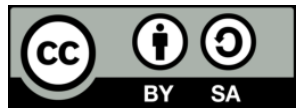

\section{Corresponding Author:}

Murdiningsih,

Department of Midwifery,

Poltekkes Kemenkes Palembang,

Jl. Jend. Sudirman/Kayu Awet No.1365, Komp. RSMH Palembang, Indonesia.

Email: murdi.ningsih1957@gmail.com.

\section{INTRODUCTION}

Physiological alteration in adolescents is puberty that is an inevitable process and first sign [1]. Adolescences haven't adequately skill of life that is being a risk to doing the negative pre-marital sexual behavior. Twenty-five percent of teen's age 15 years old have experienced sexual intercourse, resulting in sexually transmitted disease (STD) and unwanted pregnancy [2, 3]. Many studies has been reported that 66-75\% of adolescents have had sexual intercourse by the time they are in senior high school which is in 12 grade [4]. Adolescents premarital sexual behavior influenced many factors such as biological factors, genetic factors, individual perceptions, attitudes, intentions, subjective norms, personal characteristics, sociocultural values and norms [5].

The data of the Indonesian health demographic survey in 2017 was found seven percent of women in the ages 15-19 years is have become mothers, among of them is five percent was labor and two percent is the first pregnancy [6]. Unsafe sexual behavior can lead to risky pregnancy in adolescents such as an abortion, bleeding, infection, hypertension, embolism, complications in labor as well as an increased risk of maternal death [7]. The protection of sex in Indonesian adolescents was at a low level. It was influenced that the socio-cultural issue that almost people assume that sexual behavior and reproductive health is something taboo and privation to discuss $[8,9]$. Education in adolescents has been suggested to improve knowledge 
of health as well as in sexual behaviors [10]. Communication about sexuality giving a positive influence on the development of sexual in adolescents [4]. Unfortunately, a lack of communication, support, and information from parents on sexual issues are involved inability to prevent or intervene in the sexual activity of adolescents. An adolescent is assumed that the parent and many teachers as educators have a lack of skills in sexual guidance counseling and tend to judge or blame them [11].

Pradnyani, et al., was suggested that maternal education, peer norm, PIK-KRR program, attitudes, and subjective norms were effected to pre-marital sexual behavior in adolescents [12]. Adolescents can be exposed to sexy content in the media during the development period compilation of gender roles, sexy attitudes, and sexy behavior are being formed, so that it's may very risky because cognitive skills that allow them to critically analyze the media and make decisions about future results are not supported [13]. To protect the negative effect of exposure to the media sexy content, sexy attitude, and others in adolescents they should be increasing their positive knowledge about sexual behavior and reproductive health. Even though recent many education that supported ability and development of knowledge adolescent about attitude premarital sexual behavior, but that yet enough to preventing massive access media. The important role of parent it not only contributed to the adolescent attitude in reproductive health care as well as premarital sexual behavior but also education in school is more important.

\section{RESEARCH METHOD}

This was quasi-experimental research employed pre-test and post-test designs with a control group (non-equivalent control group). This research obtained 192 students from five private senior high schools in Palembang City at 2019 which were consisting of 40 students from Karya Ibu Senior High School, 32 students from Antara Senior High School, 35 students from Ethika Senior High School, 34 students from Arinda Senior High School, 51 students from Candra Dimuka Senior High School. To prove that there is an effect between the two control variables such as focus group discussion (FGD) and the intervention variable (reproductive health education), the McNemar statistical test was used and conducted the intervention two times, and the post-test to see the changes in students' behavior.

In the experimental research, especially quasi-experiments (quasi-experiments) are always questioned about their validity, both internal and external validity. Factors that influence or interfere with the validity can be referred to as threats to internal validity, including history, maturity, selection, test procedures, and instruments, and regression towards the average value. While the external validity, namely the effect of various "biases" selection, the effect of pretest implementation, experimental experiments, and multiple treatment disorders [14]. In this study we control the confounding factors used the questioner that was validated, that was used in pre-test, implementation of experiments, and posttest. To measure the Health education as an independent variable we used by learning events unit form (Satuan Acara Pengajaran) sheet and focus group discussions (FGD). To measure the adolescent behavior about premarital sex as the dependent variable we used the valid and standard of Likert scale that related to adolescent behavior about premarital sexuality. We also used the strict criteria of samples require to homogeneity of samples that is the cognitive participant skills of participants.

According to Sugiyono, some studies can use experimental designs, because the select variables and other variables or confounding variable can affect the experimental process, so to find out how much influence, one must compare (comparative) before and after, or with groups that are given treatment and groups that are not given treatment [15]. Other variables called by confounding variables in this study are sources of information, knowledge of premarital sex, knowledge of reproduction, and adolescent attitudes. Furthermore, to prove the existence of the influence between the two control variables (FGD) and the intervention variable (reproductive health education), the McNemar test was used as a statistical test. The McNemar test was carried out 2 times the intervention and a post-test to see changes in the student's behavior was to see the relationship between the information source variables, Knowledge of Premarital sex, knowledge of reproduction, and attitudes of adolescents with behavior in the intervention group were used the Chi-Square test.

\section{RESULTS AND DISCUSSION}

The participants were 192 students consisted of 127 male students and 65 female students. We divide them into two groups that the first group called the intervention group amount of 97 students and the second called control group that given a focus group discussion (FGD) amount of 95 students. All participants should be followed by the criteria of samples who were studying at least two years at the school and receive the Biology study with sub-topic is reproductive health, and accept the informed consent.

Based on the univariate pre-test analyzed this study found that the students with a lot of sources of information in good intervention behavior are $95.5 \%$, good knowledge of reproductive health is $92.9 \%$, 
and positive attitude is $96.5 \%$ as shown in Table 1. Furthermore, this study has analyzed the factors related to premarital sexual behavior. This study was found that there is no significant relationship between having a lot of information and little information about $\operatorname{sex}(\mathrm{p}=0.106)$ however, the students who have a lot of information will have $3.73 \%$ fold a better premarital sexual behavior. Furthermore, there is a significant relationship between knowledge of sex in adolescents and premarital sexual behavior $(\mathrm{p}=0.019)$ as shown in Table 1. Besides, the adolescents who have good reproductive health knowledge was $6.58 \%$ fold to be altered to a good sexual behavior after the intervention compared to adolescents with a little knowledge about the reproductive health. Furthermore, there is a significant relationship between attitude adolescents and premarital sexual behavior ( $\mathrm{p}<0.01$ ). Additionally, adolescents that have a positive attitude was $38.26 \%$ fold good perception in premarital sexual behavior after the intervention compared to a negative attitude, as more positive the adolescent's attitude the better the early sexual behavior in adolescents who have been given an intervention as shown in Table 1. Based on the McNemar test after the second intervention that was found 40 students $(93 \%)$ have well behaved from 43 students, additionally, there was a significant relationship between second intervention and premarital sexual behavior $(\mathrm{p}<0.01)$ as shown in Table 2.

\begin{tabular}{|c|c|c|c|c|c|c|c|c|}
\hline \multirow[t]{3}{*}{ Variable } & \multicolumn{4}{|c|}{ Intervention behavior } & \multicolumn{2}{|c|}{ Total } & \multirow[t]{3}{*}{ p-value* } & \multirow[t]{3}{*}{ OR $(95 \% \mathrm{CI})^{*}$} \\
\hline & \multicolumn{2}{|c|}{ Good } & \multicolumn{2}{|c|}{ Not good } & \multirow[b]{2}{*}{$\mathrm{n}$} & \multirow[b]{2}{*}{$\%$} & & \\
\hline & $\mathrm{n}$ & $\%$ & $\mathrm{n}$ & $\%$ & & & & \\
\hline \multicolumn{9}{|l|}{ Sources of Information } \\
\hline - a lot of & 42 & 95.5 & 2 & 2 & 44 & 100 & 0.106 & $3.73(0.750-18.594)$ \\
\hline - a little & 45 & 84.9 & 8 & 15.1 & 53 & 100 & & \\
\hline \multicolumn{9}{|l|}{ Knowledge of Sex } \\
\hline - good & 79 & 92.9 & 6 & 7.1 & 85 & 100 & $0.019^{*}$ & $6.58(1.53-28.32)$ \\
\hline - less & 8 & 66.7 & 4 & 33.3 & 12 & 100 & & \\
\hline \multicolumn{9}{|c|}{$\begin{array}{l}\text { Knowledge of Reproductive Health } \\
\text { - good }\end{array}$} \\
\hline - less & 85 & 99.6 & 3 & 3.4 & 88 & 100 & $0.00^{*}$ & $38.26(7.526-194.56)$ \\
\hline $\begin{array}{l}\text { Attitude } \\
\text { - positive }\end{array}$ & 2 & 22.2 & 7 & 77.8 & 9 & 100 & & \\
\hline - negative & 82 & 96.5 & 3 & 3.5 & 85 & 100 & $0.00^{*}$ & \\
\hline & 5 & 41.7 & 7 & 58.3 & 12 & 100 & & \\
\hline Total & 87 & & 10 & & 97 & 100 & & \\
\hline
\end{tabular}

OR: Odd Ratio; CI : Confidence Interval ; ${ }^{*}$-value $<0,05$

Table 2. Logistic regression test result

\begin{tabular}{|c|c|c|c|c|c|c|c|}
\hline \multirow{2}{*}{ Control behavior } & \multicolumn{4}{|c|}{ Intervention behavior } & \multicolumn{2}{|c|}{ Total } & \multirow{2}{*}{ p-value } \\
\hline & Good (n) & $\%$ & Not good (n) & $\%$ & $\mathrm{~N}$ & $\%$ & \\
\hline Good & 40 & 93 & 3 & 7 & 43 & 100 & \\
\hline Not Good & 46 & 88.4 & 6 & 11.6 & 52 & 100 & $0.00 *$ \\
\hline Total & 86 & & 9 & & 95 & & \\
\hline
\end{tabular}

\subsection{Sources of information}

The information about sex can be obtained from mass media (print or electronic), parent, health service officer, teacher, and friend. The present study result showed prevalence and patterns of pornography in the majority of students use online streaming videos as the most popular form of use [14]. This result was found that the $\mathrm{p}$-value is $0.106>0.05$ which means that there is no significant relationship between getting a lot of information and less information about sex. The result of OR is 3.73 which means that students who obtained a lot of information about sex will have good sexual behavior. They have a chance of 3.7 times doing premarital sex behavior compared with the ones that obtained less information about sex. It's similar to the statement that the adolescents who accessed pornography information by watching media was increased risky sexual practices [15-18].

\subsection{Knowledge of sex}

A low knowledge is increased risky sexual behavior [19], The adolescent commonly searched or receive related information about the early stage of the puberty period such as physical changes and psychological adaptation before sexual reproduction health information is equipped [1]. The knowledge about sex is very important for adolescents to have. It is not only illness and death caused by human reproduction that is matters of concern but also the social consequences of sexual activity among young unmarried adults such as pregnancy and early parenthood [20]. The positive impact of getting the right information and knowledge about sex is able to prevent premarital sex behavior, unwanted pregnancy, 
HIV/AIDS, and sexually transmitted infections (IMS) [10]. From this variable, the p-value is $0.019<0.05$ which means that there is a significant relationship between having a good knowledge of sex and premarital sexual behavior. The OR of this variable is 6.58 which mean that the students who have good knowledge of sex will have a chance 6.58 times behaving good premarital sex compared with the fewer ones.

In line with Menna et al., was suggest that the effects of a peer education intervention on HIV/AIDS is related to sexual behaviors of secondary school students in Addis Ababa, Ethiopia students in the intervention group were more likely to use condoms during the period post-intervention compared to students from group control [21], as well as De Lijster suggested that a combination of the play and the lessons have the potential to prevent sexual harassment behavior [22]. From this result, it can be seen that it is very important for adolescents to increase their knowledge of sex and reproductive health to the maximum level by searching the right sources which are credible and involving various parties like school, parent, and environment in general. Having less knowledge about premarital sex behavior can lead adolescents to the wrong attitude and then affecting their sexuality. Besides these factors, some adolescents have a perception that having sex is a way to express love, so that only for love they surrender their virginity by having sex with the one that they love before marriage.

\subsection{Knowledge of reproductive health}

Knowledge is one of the main factors that promote healthy behaviors and reduces risk-taking behaviors [10]. Based on the result above, the p-value of students who have good knowledge of reproductive health after the interventions is $0.00<0.05$. This means that there is a significant relationship between the knowledge of reproductive health and premarital sexual behavior. From this variable, the OR result is 99.16 which means that students who have good knowledge of reproductive health will have good behavior 99.16 times compared with the ones who less. Even though there is no formal evaluation of comprehensive sexual education implementation in adolescents, but this program is promising and suggest to delay sexual debut and prevent risky sexual behavior among adolescents [23, 24]. More ever, this result is in line with De Castro, et al was suggested to promoting the education of comprehensive sexual and reproductive health that was associated with positive perception about sexual and reproductive health in Mexican senior high school students [25].

In addition according to Pawestri, et al., which shows that there is a significant relationship between the knowledge and the sex behavior on students at State Senior High School No.1 (SMA Negeri 1) Godong with $p$-value $=0.00(p<0.05)[10]$. Furthermore regarding this result, we can see how important the role of the knowledge about sex and reproductive health for adolescents. They can increase their knowledge by searching various sources which are appropriate and credible, and involving various parties like school, parent and environment in general.

\subsection{Attitude}

Attitude is a closed reaction or response of someone to a stimulus or an object. Manifestation of attitude cannot be guessed, but can only be interpreted through closed behavior. An attitude that clearly shows the connotation of the suitability of a reaction to a particular stimulus in daily life is an emotional reaction to the social stimulus [26]. Based on the result, the p-value of students who have a positive attitude after the intervention is 0.00 . It means that there is a significant relationship between positive and negative attitudes on premarital sexual behavior. The result of the OR is 38.26 which mean that the students who have a positive attitude will have 38.26 chances of behaving good premarital sex compared with the fewer ones.

Based on the result, the p-value of students who have a positive attitude after the intervention is 0.00. It means that there is a significant relationship between positive and negative attitudes on premarital sexual behavior. The result of the OR is 38.26 which mean that the students who have a positive attitude will have 38.26 chances of behaving good premarital sex compared with the fewer ones. This was similar to The Rank Spearman test from this variable is 0.268 which means that the more positive the attitude, the better the premarital sexual behavior [27]. In the other hand, the result of this variable is following the study conducted by Pawestri, et al., which suggested there is a significant relationship between attitude and premarital sex behavior on students at SMA Negeri 1 (State Senior High School No.1) Godong with the p-value 0.017 ( $<<0.05$ ). Furthermore, Iordanescu, et al., was suggested that sexual behavior and attitudes toward sex are important things in adolescents as a consequence of a critical period from the transition phase both psychologically and socially in teenagers [28]. Susanto et al., found that there was a significant effect of attitude on premarital sexual behavior. Adolescents with weak attitudes were more likely to engage in risky sexual behavior, in addition many studies ware suggested that attitude was a predisposing factor that included components such as beliefs, ideas, concepts, and emotional expressions that were expressed with behavior which related to action [15, 29-31]. 


\section{CONCLUSION}

The sexual behavior of adolescents is getting better after intervention. Furthermore, after conducted the intervention and connected to the confounding variable, there are changes in the sexual behavior of the adolescents with p-value 0.00. It means that there is an effect the intervention toward sexual behavior among adolescent. The most dominant factor that is affecting the adolescents' behavior on the premarital sex behavior is the knowledge of reproductive health ( $p$-value 0.00). This study suggested that information about adolescent reproductive health should be included in the curriculum, especially in Biology class.

\section{ACKNOWLEDGEMENTS}

We gratefully thank Polytechnic of Health of Palembang, health human resources development and empowerment agency (BPPSDM), and the Ministry of Health of Indonesian.

\section{REFERENCES}

[1] S. Nurdjannah, "Knowledge and behaviour about adolescent reproductive health in Yogyakarta, Indonesia," International Journal Public Health Science, vol. 4, no. 4, pp. 326-331, 2015.

[2] W. H. O.-W. Geneva, "WHO Guidelines on preventing early pregnancy and poor reproductive outcomes among adolescents in developing countries," 2011.

[3] V. Chandra-Mouli, A. V. Camacho, and P.-A. Michaud, "WHO Guidelines on Preventing Early Pregnancy and Poor Reproductive Outcomes Among Adolescents in Developing Countries) 517e522," Journal Adolescent Health, vol. 52, vol. 5, pp. 517-522, 2013.

[4] C. L. Somers, S. Tolia, and C. Anagurthi, "Parent-Adolescent Relationships and Adolescent Sexual Behavior: Patterns by Adolescent Gender," International Journal of Business and Social Science, vol. 3, no. 7, pp. 66-76, 2012.

[5] R. Sieving, A. Jennifer, and R. Blum, "Adolescent Sexual Behavior and Sexual Health," Pediatric Review, vol. 23, no. 12, pp. 407-416, 2017.

[6] BKKBN, BPS, and Kemenkes RI, “Survei Demografi Kesehatan Indonesia,” Usaid, pp. 1-606, 2018.

[7] S. Neal et al., "The causes of maternal mortality in adolescents in low and middle income countries: a systematic review of the literature," BMC Pregnancy Childbirth, vol. 16, no. 352, pp. 1120-8, 2016.

[8] I. Putra, D. Astuti, and D. Widyastari, "Prevalence and determinants of condom use among male adolescents in Indonesia," International Journal of Adolescent Medicine and Health, vol. 0141, pp. 1-8, 2018.

[9] T. Susanto et al., "Prevalence of factors related to active reproductive health behavior: A cross-sectional study Indonesian adolescent," Epidemiology Health, vol. 38, pp. 1-10, 2016.

[10] G. Mahat, M. A. Scoloveno, T. De Leon, and J. Frenkel, "Preliminary Evidence of an Adolescent HIV/AIDS Peer Education Program,” Journal Pediatric Nurse, vol. 23, no. 5, pp. 358-363, Oct. 2008.

[11] T. S. Makhitha and P. Botha, "Teenagers' Sexual Activities On School Grounds: A Need For Social Work Support," Social Work/Maatskaplike Werk, vol. 53, no. 4, pp. 496-516, Oct. 2017.

[12] P. Pradnyani, I. Putra, and N. Astiti, "Knowledge, attitude, and behavior about sexual and reproductive health among adolescent students in Denpasar, Bali, Indonesia," Global Health Management Journal, vol. 3, no. 1, pp. 31-39, 2019.

[13] E. Gruber and J. W. Grube, "Adolescent sexuality and the media: A review of current knowledge and implications," Western Journal Medical, vol. 172, no. 3, pp. 210-214, 2000.

[14] A. Dwulit and P. Rzymski, "Prevalence, Patterns and Self-Perceived Effects of Pornography Consumption in Polish University Students: A Cross-Sectional Study," International Journal Environmental Research Public Health, vol. 16, no. 10, p. 1861, 2019.

[15] B. N. A. Susanto, I. D. A. Nurhaeni, and E. P. Pamungkasari, "Do Schools Affect Unsafe Sexual Behaviors among High School Students in Boyolali, Central Java? A Multilevel Analysis Approach," J. Heal. Promot. Behav., vol. 3, no. 4, pp. 230-239, 2018.

[16] A. Muche, G. Kassa, A. Berhe, and G. Fekadu, "Prevalence and determinants of risky sexual practice in Ethiopia: Systematic review and Meta-analysis," Reproduction Health, vol. 14, no. 1, p. 113, 2017.

[17] J. Espada, A. Morales, A. Guillen-riquelme, R. Ballester, and M. Orgiles, "Predicting condom use in adolescents: a test of three socio-cognitive models using a structural equation modeling approach," BMC Public Health, vol. 16, no. 35, pp. 1-10, 2016.

[18] R. Nonsi, L. Ahmad, and I. Pagala, "Factors Related to Sexual Behavior in SMA Negeri 5 Kendari in 2015 (Faktor yang Berhubungan dengan Perilaku Seksual pada Siswa SMA Negeri 5 Kendari tahun 2015)," Jurnal Ilmu Mhs. Kesehat. Masy., vol. 1, no. 2, pp. 1-10, 2016.

[19] P. Brüll, R. Ruiter, R. Wiers, and G. Kok, "Identifying psychosocial va-riables that predict safer sex inten-tions in adolescents and young adults," Front. Public Heal., vol. 4, no. 74, pp. 1-10, 2016.

[20] Faturochman, "Understanding premarital sexual attitude and behaviour: theoretical and empirical contexts," Bulletin Psikology, vol. 11, no. 1, pp. 47-64, 2003.

[21] T. Menna, A. Ali, and A. Worku, "Effects of peer education intervention on HIV/AIDS related sexual behaviors of secondary school students in Addis Ababa, Ethiopia: A quasi-experimental study," Reprodution Health, vol. 12, no. 1 , pp. 1-8, 2015. 
[22] G. P. A. de Lijster, H. Felten, G. Kok, and P. L. Kocken, "Effects of an Interactive School-Based Program for Preventing Adolescent Sexual Harassment: A Cluster-Randomized Controlled Evaluation Study," J. Youth Adolesc., vol. 45, no. 5, pp. 874-886, 2016.

[23] X. Chi, S. Hawk, S. Winter, and W. Meeus, "The effect of comprehensive sexual education program on sexual health knowledge and sexual attitude among college students in Southwest China," Asia Pac J Public Heal., vol. 27, no. 2, pp. 2049-66, 2015.

[24] D. Kirby and N. Ecker, "International technical guidance on sexuality education: an evidence informed approach for schools, teachers and health educators," Paris, France: United Nations Educational, Scientific and Cultural Organization, 2009.

[25] F. De Castro et al., "Sexual and reproductive health outcomes are positively associated with comprehensive sexual education exposure in Mexican high-school students," PLoS One, vol. 13, no. 3, p. 5, 2018.

[26] Notoatmodjo, "Health Promotion Theories and Applications (Promosi Kesehatan Teori dan Aplikas)," Jakarta: PT. Rineka Cipta, 2010.

[27] Pawestri et al, "Knowledge, attitudes and behavior of adolescents about premarital sex (Pengetahuan, sikap dan perilaku remaja tentang seks pra nikah)," J. Keperawatan Matern., vol. 1, no. 1, pp. 46-54, 2015.

[28] E. Iordanescu, C. Iordanescu, and A. Draghici, "Time and Gender Influence in Sexual Behavior of Romanian Adolescents.," Procedia - Soc. Behav. Sci., vol. 187, pp. 757-761, 2015.

[29] J. Park et al., "A 10-Year Interval Study About the Sexual Life and Attitudes of Korean Women: The Korean Internet Sexuality Survey (KISS) 2014, Part 2,” J. Sex. Med., vol. 14, no. 9, pp. 1142-1151, 2017.

[30] A. Idowu, A. Ayodele, P. Omotade, O. Anu, and F. Omolola, "Risky Sexual Behavior of Senior Secondary School Students in an Urban Community of Oyo State, South West Nigeria," Int. Q. Community Health Educ., vol. 37, no. 3-4, pp. 173-180, 2017.

[31] A. Scalco, S. Noventa, R. Sartori, and A. Ceschi, "Predicting organic food consumption: A meta-analytic structural equation model based on the theory of planned behavior," Appetite, vol. 112, pp. 235-248, 2017. 